\title{
Behavioral Pattern of Overweight and Obese School Children
}

\author{
Vesna Jureša ${ }^{1}$, Vera Musil ${ }^{1}$, Marjeta Majer ${ }^{1}$, Davor Ivanković ${ }^{2}$ and Davor Petrović ${ }^{3}$ \\ ${ }^{1}$ University of Zagreb, School of Medicine, "Andrija Štampar « School of Public Health, Department of Social Medicine \\ and Organization of Health Care, Zagreb, Croatia \\ ${ }^{2}$ University of Zagreb, School of Medicine, »Andrija Štampar« School of Public Health, Department of Medical Statistics, \\ Epidemiology and Medical Informatics, Zagreb, Croatia \\ ${ }^{3}$ University of Zagreb, Zagreb University Hospital Centre, Department of Gynecological and Prenatal Pathology, Zagreb, Croatia
}

\begin{abstract}
A B S T R A C T
The aim of this study was to determine socio economic, health status, nutritional and behavioral differences in obese, overweight and normal weight children attending first grade elementary school. In overweight group there is $13.8 \%$ of boys and $12.6 \%$ of girls, in obese group $8.3 \%$ of boys and $6.9 \%$ of girls. In factor analysis 12 factors was excluded with cumulative loading of 60\% variability. Discriminant analysis was performed with 12 factors as predictive variables and discriminant variables were three BMI groups: normal weight, overweight and obese. Function 1 discriminate well normal weight group from overweight and obese group. Overweight and obese groups is described with lower number of children in the family and lower order of birth, higher education of parents, they eat less vegetables and fruits, spend more time playing computer games, have less physical activity, drink more alcohol with their meals, exactly opposite to normal weight group.
\end{abstract}

Key words: children, habits, obesity, overweight

\section{Introduction}

Overweight and obesity are considered as one of the important risk factors for development of chronic diseases. The increased prevalence of overweight and obesity among children and adolescents is a major public health problem in the world ${ }^{1}$. Onset is usually in childhood and could be modified by changes in nutritional and life style habits. The proportion of food from restaurants and fast food outlets that children consume increased by $300 \%$ between $1977-1996,16 \%$ of children aged $6-11$ years are overweight ${ }^{2}$.

Aim of this study was to determine socio economic, health status, nutritional and behavioral differences in obese, overweight and normal weight children attending first grade elementary school.

\section{Materials and Methods}

Methodology for sampling was developed during project School Health Survey 2003-2004 part of 2003 Croatian Adult Health Survey conducted in collaboration of
Croatian Ministry of Health and Social Welfare and Canadian Society for International Health and supported by Ministry of Science, Education and Sport ${ }^{3}$. Data about number of schools, classes and children attending all primary and secondary schools in Croatia were gathered from Croatian Ministry of Education. This survey targeted school children at primary school grades I and VIII aged $7(6.50-7.49)$ and aged $14(13.50-14.49)$ years, and at secondary school grade III aged 17 (16.50-17.49) living in Croatia. For various reasons this survey component covers $95 \%$ of the targeted age groups. Study comprehends children from representative sample of 40 primary and 20 secondary schools. The methodology of School Health Survey was described in the special paper in the latest issue of the journal ${ }^{4}$. The present study included 960 school children 493 (52.4\%) boys and 467 (48.6\%) girls in $1^{\text {st }}$ grade of primary school. In total 3,101 individuals were selected to participate in the School Health Survey 2003-2004. Out of these selected individuals a response was obtained for 2851 individuals which results in an overall response rate of $91.9 \%$. The response rate in

Received for publication September 1, 2011 
primary school $1^{\text {st }}$ grade was $92.8 \%$. Schools were informed in advance by letter that The Survey would be performed and provided with the description of the research. Because of the non-invasive nature of the protocol consisting only of questionnaire and measurements considered routine for school-entry/sports-participation and regular systematic examinations (i.e. height, weight, and blood pressure), a "passive consent« process was used. Parents/guardians and children were provided with a form on the first page of questionnaire that was to be returned if parents/guardians did not wish their child (or children personally) did not wish to participate. Method for obtaining data was questionnaire, completed by parents, with 75 questions about computer and internet use, watching television, eating and drinking habits, children's health status, and parent's education. Anthropometric measurements: body height and weight and blood pressure $^{4}$. Questionnaire School Health Survey consisted of following group of questions and answerers:

A. Family structure - Education of father and mother (incomplete primary school, primary school, three - year secondary school, four - year secondary school, college, university, unknown, not stated); Father and mother-employment status (employed, unemployed, student, retired, desist, not stated) Occupation of father and mother (manager and politician, professional and scientists, engineer and technician, clerk or official and employee, service and commercial trade, farmer or forest worker or fisherman, craftsman and manufacture, heavy equipment operators and drivers, simple occupation, military service, unknown, not stated); Number of children in the family; Order of birth (firstborn, second born, third born, fourth born and more, not stated);

B. Socio economic, demographic characteristics of selected respondent - Elementary School/Secondary school (code, grammar, three year secondary school, four year secondary school); Grade (1st grade, 2nd grade, .....); Class (a, b, c,.....); Gender (male, female); Date of birth (day, month, year); Where was child born? (1. Zagreb, Split, Rijeka, Osijek and towns with more than 200,001 inhabitants, 2. 10,001 do 200,000 inhabitants, 3. 5,001 do 10,000 inhabitants, 4. 2,001 do 5,000 inhabitants, 5. $<2,000$ inhabitants, 6. abroad, 7. not stated); Where does child live now? 1. Zagreb, Split, Rijeka, Osijek and towns with more than 200,001 inhabitants, 2. 10,001 do 200,000 inhabitants, 3. 5,001 do 10,000 inhabitants, 4. 2,001 do 5,000 inhabitants, 5 . $<2,000$ inhabitants, 6 . abroad, 7. not stated); Scholastic ability last year (correct average);

C. Dietary habits - How many times a day does you/your child eat (number of meals, including a school meal)? (once, twice, three times, four times, five and more times, not stated); How many times did you/your child eat fruit yesterday?; How many times did you/your child eat vegetables or salad yesterday? (not once, once, twice, three times, four times, five and more times, not stated); How many times in the past 7 days did you/your child eat a hamburger, hotdog, cold meat, sandwiches?; How many times in the past 7 days did you/your child eat meat (except "fast food»)? (not once, once, twice, three times, four times, five and more times, six times, seven and more times, not stated); How much milk does you/ your child drink a day? (he/she doesn't drink milk at all, one cup/glass (2dl) a day, two cups/glasses a day, three cups/glasses a day, four to five cups/glasses a day, more than five cups/(more than 1litre), not stated: How many coffee spoons of sugar does you/your child put into cocoa/milk with coffee?; How many coffee spoons of sugar does you/your child put into tea? (not one, one, two, three, four, five, six and more, my child doesn't drink it, not stated): How many times in the past 7 days did your child eat sweets (chocolate, ice-cream, cakes and other)? (not once, once, twice, three times, four times, five and more times, six times, seven and more times, not stated);

D. Physical activity - Does you/your child exercise (or train) in some sports club, school sports club or elsewhere (gym, fitness center, aerobics, etc)? (yes, no, not stated); How often does you/your child exercise in his/her leisure time in a way that he/she sweats a lot or cannot take a breath? (every day, 4-6 times a week, 2-3 times a week, once a week, once a month, less than once a month, never, He/she doesn't exercise for health reasons/(disease or other health reasons, not stated), How often did your child walk or run for more than $30 \mathrm{~min}$ utes in the past 7 days?; How often did your child ride a bicycle for more than 30 minutes in the past 7 days? (not once, once, twice, three times, four times, five and more times, six times, seven and more times, not stated); Is you/your child exempt from physical training at school? (yes completely, yes partially, no, not stated);

E: TV and PC - How many hours a day does your child watch a television, on an average day?; How many hours a day does your child do the games or work on a computer? (he/she doesn't play on computer, about 1 hour, about 2 hours, about 3 hours, hours and longer, not stated);

F. Alcohol and smoking - Has you/your child ever in his/her life smoked cigarettes or take a puff or two?; Has you/your child ever drunk an alcoholic drink? (yes, no, not stated); How many times did you/your child drink at least one glass of alcoholic drink with your food (meal) in the past 30 days? (not once, 1-2 times, 3-5, 6-9, 10-19, 20-29, every day, not stated);

G. Teeth hygiene - How often does you/your child brush his/her teeth? (twice a day or more often, once a day, at least once a week but not every day, less than once a week, never, not stated);

H. Traffic safety - How often does you/your child fasten a seatbelt when he/she drives in a car? (always, often, sometimes, rarely or never, usually there is no seat belt where he/she is sitting, not stated); How often did your child ride (as driver or co driver) a motorbike in the past 30 days? (never, 1-7 times, 8-14 times, 15-24 times, more than 25 times, not stated);

I. Physical conflicts - How often did you/your child have a fight in the past 12 months? (not once, once, 2-3 times, 4-5 times, 6-7 times, 8-9 times, 10 and more 
times, not stated), Has you/your child ever been bullied by another child? (yes, no, not stated);

J. Health problems, status and symptoms - How often in past six months did you/your child have anything of the mentioned? (same answer for every question): Headache, Abdominal pain/cramps, Pains in the back, Feeling of lack of spirit, Feeling of irritation, Nervousness, Difficulties with sleeping, Dizziness (every day, more often than once a week, more often than once a month, approximately once a month, rarely or never, not stated); Has your child in the past month taken any medication (pills, syrup and other)? (same answer for every question) for: cough, cold, headache, abdominal pains, For sleeping, nervousness, something else (yes, no, not stated); Has you/your child in the past three years visited a physician for difficulties with (same answer for every question): Received injury, Allergy, Reproductive system, Heart and cardiovascular system, Liver, Lungs, Kidneys and urinary system, Blood, Digestive organs, Thyroid (yes, no, not stated); Assess how your/your child's health is: excellent, very good, good, fair, bed, not stated;

K. Family medical history - Illness in the family :father, mother, brothers, sisters, grandmothers and grandfathers of your child (same answer for every question): Elevated blood pressure, Heart diseases, Diseases of thyroid, Increased fats in the blood, Diabetes, Other diseases (yes, no, not stated). Anthropometric measurements body height, body weight, blood pressure, heart rate.

Procedure lasted approximately 5-7 minutes per one pupil, and was executed by team of examiners - medical doctors. Children were measured wearing light clothes and no shoes in calm, quite and comfortable setting. Body weight was measured on calibrated digital scale (Seca 862) and recorded to the nearest 100 grams and body height was measured with head positioned in Frankfurt plane by a fixed wall-mounted stadiometer and recorded to nearest 0.1 centimeters. At $10 \%$ of subjects measurement of body height and weight was repeated for control use. Data for this study were obtained from completion of questionnaire and physical examination. On the basis of the data obtained by measurements, body mass index (BMI) as weight/height ${ }^{2}\left(\mathrm{~kg} / \mathrm{m}^{2}\right)$. Accordingly to BMI children were divided in three groups by »Cole standards « (International cut off points for body mass index for overweight and obesity by sex between 2 and 18 years, defined to pass trough body mass index of 25 and $30 \mathrm{~kg} / \mathrm{m}^{2}$ at age 18 , obtained by averaging data from Brazil, Great Britain, Hong Kong, Netherlands, Singapore, United States): group 1 - Normal weight, group 2 - Overweight $\left(25 \mathrm{~kg} / \mathrm{m}^{2}\right)$ and group 3 - Obese (30 $\left.\mathrm{kg} / \mathrm{m}^{2}\right)^{5}$.

Descriptive statistics was used to describe the distributions of variables, factor analysis and factor discriminant analysis. The Statistica 9.0 was used for data analysis.

\section{Results}

In the group of our first grade pupils mean age is 7.5 years. According to "Cole standards « in overweight group there $13.8 \%$ of boys and $12.6 \%$ of girls, in obese group $8.3 \%$ of boys and $6.9 \%$ of girls (Table 1 ).

Children's family structure is described with group of variables: Education of father and mother, number of children in the family and order of birth. In all three groups by BMI $45 \%$ and more of the parents completed four year secondary school, overweight group of children have highest percentage of parents with university education $11.8 \%$ fathers and $12.6 \%$ mothers. Five and more children are most common in normal weight group. Obese group children most often don't eat fruit (12.3\%) and vegetable (13.7\%). Normal weight and overweight group children eat fast food less than obese group children. Obese group children do not have children who didn't eat meat in past seven days. Obese group children show somewhat less physical activity (run or driving bicycle). Overweight and obese group children spend more time playing computer games and watching video. Overweight group children experience less lack of spirit and irritation, headache and abdominal pains than other two groups (Table 2).

All variables which meet the criteria were included in factor analysis and 12 factors were excluded with cumulative loading of $60 \%$ variability. Nine of twelve factors were described with clear groups of variables and could be named (Table 3).

In Table 4 are shown factors included in analysis with questions contributing each factor and their loading. Factor 1 is described with unwillingness, anxiousness

TABLE 1

PARTICIPANTS BY GENDER AND BMI GROUPS

\begin{tabular}{|c|c|c|c|c|c|c|c|c|}
\hline \multirow{3}{*}{ Gender } & \multicolumn{8}{|c|}{ BMI $\left(\mathrm{kg} / \mathrm{m}^{2}\right)$} \\
\hline & \multicolumn{2}{|c|}{$\begin{array}{c}\text { Group } 1 \\
\text { Normal weight }\end{array}$} & \multicolumn{2}{|c|}{$\begin{array}{c}\text { Group } 2 \\
\text { Overweight* }\end{array}$} & \multicolumn{2}{|c|}{$\begin{array}{l}\text { Group } 3 \\
\text { Obese* }\end{array}$} & \multicolumn{2}{|c|}{ Total } \\
\hline & $\mathrm{N}$ & $\%$ & $\mathrm{~N}$ & $\%$ & $\mathrm{~N}$ & $\%$ & $\mathrm{~N}$ & $\%$ \\
\hline Boys & 384 & 77.9 & 68 & 13.8 & 41 & 8.3 & 493 & 100.0 \\
\hline Girls & 367 & 80.5 & 59 & 12.6 & 32 & 6.9 & 467 & 100.0 \\
\hline Total & 760 & 79.3 & 127 & 13.2 & 73 & 7.6 & 960 & 100.0 \\
\hline
\end{tabular}

$*$ *Cole standard» 
TABLE 2

DESCRIPTIVE CHARACTERISTICS OF THE SAMPLE - CHILDREN FIRST GRADE ELEMENTARY SCHOOL BY BMI GROUP

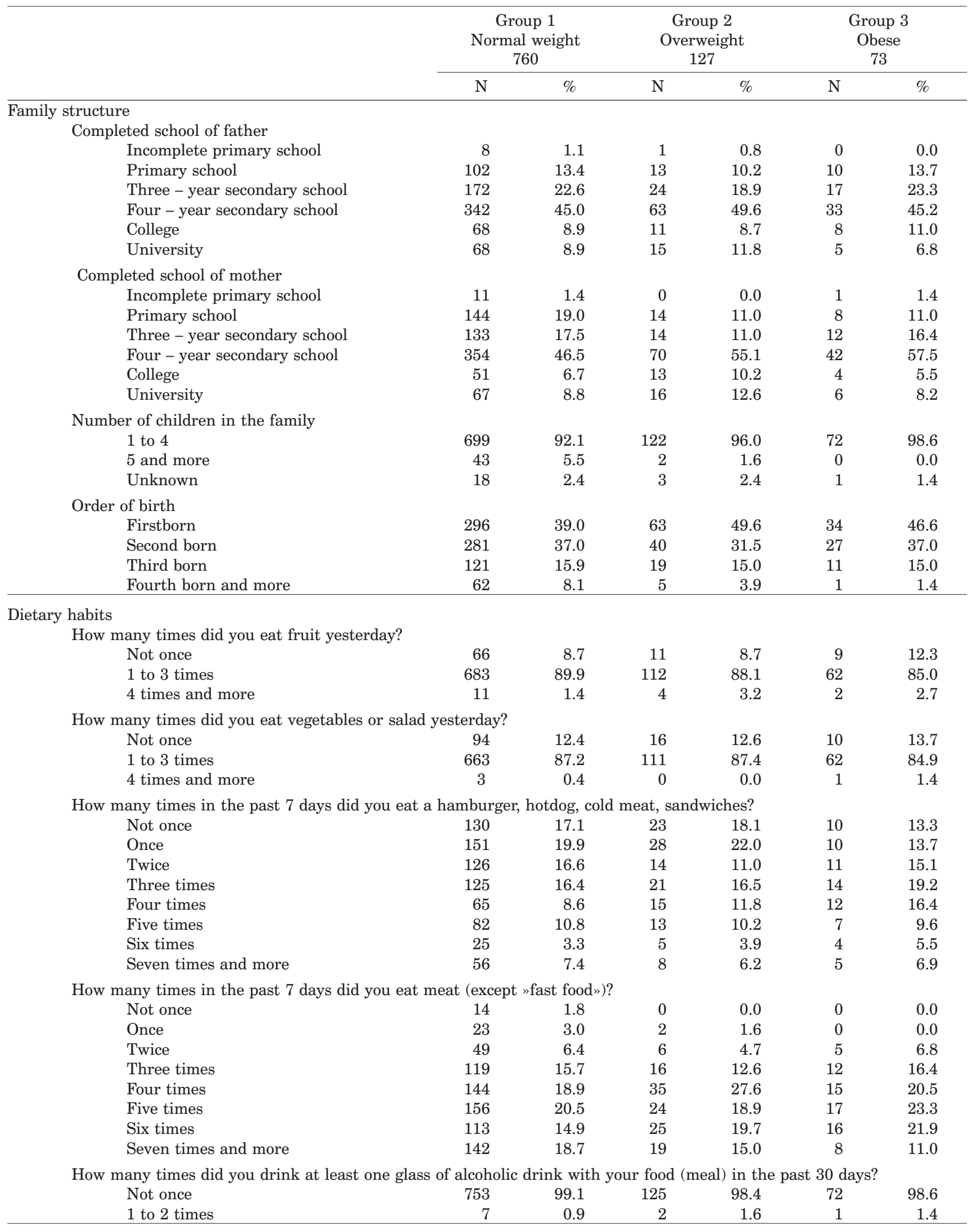




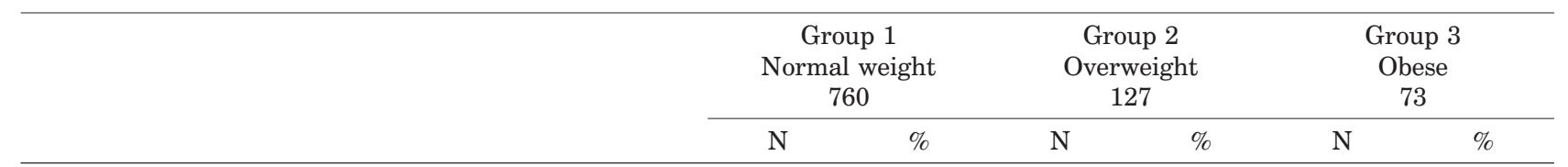

Physical activity /inactivity

How often do you exercise in your leisure time in a way that you sweat a lot or cannot take a breath?

\begin{tabular}{|c|c|c|c|c|c|}
\hline 2 to 7 times/week & 513 & 67.5 & 90 & 70.9 & 53 \\
\hline Once a week & 108 & 14.2 & 16 & 12.6 & 11 \\
\hline Once a month & 29 & 3.8 & 0 & 0.0 & 1 \\
\hline Less than once a month & 110 & 14.5 & 21 & 16.5 & 8 \\
\hline
\end{tabular}

How often did you walk or run for more than 30 minutes in the past 7 days?

$\begin{array}{lccrrrr}\text { Not once } & 89 & 11.7 & 10 & 7.9 & 10 & 13.7 \\ 1 \text { to } 3 \text { times } & 303 & 39.9 & 61 & 48.0 & 35 & 47.9 \\ 4 \text { times and more } & 368 & 48.4 & 56 & 44.1 & 28 & 38.4 \\ \text { ften did you ride a bicycle for more than } 30 \text { minutes in the past } 7 \text { days? } & & & & \\ \text { Not once } & 331 & 43.6 & 63 & 49.6 & 37 & 50.7 \\ 1 \text { to } 3 \text { times } & 280 & 36.9 & 42 & 33.0 & 22 & 30.1 \\ 4 \text { times and more } & 149 & 19.5 & 22 & 17.4 & 14 & 19.2 \\ \text { pent playing video and computer games } & & & & & & \\ \text { None } & 420 & 55.2 & 55 & 43.3 & 33 & 45.1 \\ \text { About 1 hour } & 275 & 36.2 & 67 & 52.8 & 31 & 42.5 \\ \text { About 2 hours } & 55 & 7.2 & 4 & 3.1 & 8 & 11.0 \\ \text { About } 3 \text { hours } & 8 & 1.1 & 0 & 0.0 & 1 & 1.4 \\ 4 \text { hours and longer } & 2 & 0.3 & 1 & 0.8 & 0 & 0.0\end{array}$

Psychic manifestations

Feeling of lack of spirit

Every day

More often than once a week

More often than once a month

Approximately once a month

Rarely or never

$\begin{array}{rr}3 & 0 . \\ 17 & 2.2 \\ 42 & 5.5 \\ 105 & 13.8 \\ 593 & 78.0\end{array}$

\section{4}

2.2

5.5

13.8

78.0

Feeling of irritation

Every day

More often than once a week

More often than once a month

Approximately once a month

Rarely or never

$\begin{array}{rrrrrr}3 & 0.4 & 0 & 0.0 & 0 & 0.0 \\ 17 & 2.2 & 3 & 2.4 & 4 & 5.5 \\ 42 & 5.5 & 5 & 3.9 & 6 & 8.2 \\ 105 & 13.8 & 12 & 9.4 & 14 & 19.2 \\ 593 & 78.0 & 107 & 84.2 & 49 & 67.1 \\ & & & & & \\ 16 & 2.1 & 1 & 0.8 & 2 & 2.7 \\ 35 & 4.6 & 7 & 5.5 & 0 & 0.0 \\ 87 & 11.4 & 15 & 11.8 & 8 & 11.0 \\ 145 & 19.1 & 20 & 15.7 & 17 & 23.3 \\ 477 & 62.8 & 84 & 66.1 & 46 & 63.0 \\ & & & & & \\ 9 & 1.2 & 0 & 0.0 & 1 & 1.4 \\ 40 & 5.3 & 10 & 7.9 & 2 & 2.7 \\ 70 & 9.2 & 6 & 4.7 & 6 & 8.2 \\ 107 & 14.1 & 17 & 13.4 & 9 & 12.3 \\ 534 & 70.3 & 94 & 74.0 & 55 & 75.3\end{array}$

Nervousness

$\begin{array}{lrrrrrr}\text { Every day } & 9 & 1.2 & 0 & 0.0 & 1 & 1.4 \\ \text { More often than once a week } & 40 & 5.3 & 10 & 7.9 & 2 & 2.7 \\ \text { More often than once a month } & 70 & 9.2 & 6 & 4.7 & 6 & 8.2 \\ \text { Approximately once a month } & 107 & 14.1 & 17 & 13.4 & 9 & 12.3 \\ \text { Rarely or never } & 534 & 70.3 & 94 & 74.0 & 55 & 75.3\end{array}$

Somatic manifestations

Headache

Every day

More often than once a week

More often than once a month

Approximately once a month

Rarely or never

70.3

Abdominal pains/cramps

Every day

More often than once a week

More often than once a month

Approximately once a month

Rarely or never

$\begin{array}{rrrrrr}2 & 0.3 & 0 & 0.0 & 0 & 0.0 \\ 15 & 2.0 & 1 & 0.8 & 4 & 5.5 \\ 25 & 3.3 & 2 & 1.6 & 1 & 1.4 \\ 58 & 7.6 & 12 & 9.4 & 5 & 6.8 \\ 660 & 86.8 & 112 & 88.2 & 63 & 86.3\end{array}$

Pains in the back

Every day

More often than once a week

More often than once a month

Approximately once a month

Rarely or never

$\begin{array}{rrrrrr}5 & 0.7 & 0 & 0.0 & 0 & 0.0 \\ 26 & 3.4 & 3 & 2.4 & 3 & 4.1 \\ 39 & 5.1 & 4 & 3.1 & 5 & 6.8 \\ 109 & 14.3 & 18 & 14.2 & 11 & 15.1 \\ 581 & 76.5 & 102 & 80.3 & 54 & 74.0\end{array}$

$581-76.5$

102

80.3

74.0

$\begin{array}{rrrrrr}2 & 0.3 & 0 & 0.0 & 0 & 0.0 \\ 2 & 0.3 & 1 & 0.8 & 1 & 1.4 \\ 5 & 0.7 & 1 & 0.8 & 1 & 1.4 \\ 15 & 2.0 & 2 & 1.6 & 0 & 0.0 \\ 736 & 96.8 & 123 & 96.8 & 71 & 97.3\end{array}$


TABLE 3

FACTOR ANALYSIS EXCLUDED 12 FACTORS WITH CUMULATIVE LOADING OF 60\% VARIABILITY

\begin{tabular}{|c|c|}
\hline Factors & $\%$ of variance for \\
\hline Factor 1: »Psychic manifestations « & 6.936 \\
\hline Factor 2: »Parent's education « & 6.647 \\
\hline $\begin{array}{c}\text { Factor 3: } \text { Order of birth and number of } \\
\text { children in family }\end{array}$ & 5.894 \\
\hline Factor 4: »Somatic manifestations« & 5.270 \\
\hline Factor 5: »Physical activity « & 5.228 \\
\hline Factor 6: "Meat meals« & 5.203 \\
\hline Factor 7: »Fruit and vegetable « & 4.684 \\
\hline Factor 8: »No specific name« & 4.528 \\
\hline Factor 9: »No specific name« & 4.144 \\
\hline Factor 10: »No specific name« & 3.983 \\
\hline Factor 11: »Alcohol « & 3.867 \\
\hline $\begin{array}{c}\text { Factor 12: » Time spent playing video and } \\
\text { computer games « }\end{array}$ & 3.842 \\
\hline
\end{tabular}

\section{Function 1}

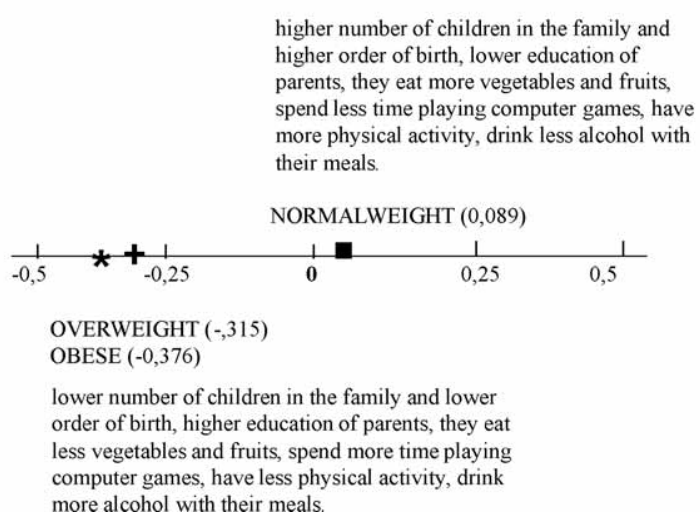

Fig. 1. Discriminant function at group centroids.

and nervousness. Factor 2 is described with father's and mother's education. Factor 3 is described with order of birth and number of children in family. Factor 4 is described with headaches, abdominal and back pains. Factor 5 is described with running, physical exercise and cycling. Factor 6 is described with eating fast food and meat. Factor 11 is described with alcohol drinking. Factor 12 is described with time spent playing computer games and watching video.

Discriminant analysis (Table 5) was performed with 12 factors as predictive variables, two functions were obtained of which only function 1 was interpretable. Function 1 was described with: »Order of birth and number of children in family « (factor 3), »Parent's education « (factor 2), Fruit and vegetable « (factor 7), »Time spent playing video and computer games « (factor 12), »Physical activity « (factor 5) and »Alcohol« (factor 11). Discriminant variables were three BMI groups: normal weight, over-
TABLE 4

QUESTIONS FORMING FACTORS INCLUDED IN ANALYSIS

\begin{tabular}{lc}
\hline $\begin{array}{l}\text { FACTOR } \\
\text { (name) }\end{array}$ & Questions \\
& Rotated Component \\
Matrix
\end{tabular}

Factor 1.

Psychic manifestations

$\begin{array}{ll}\text { Unwillingness last } 6 \text { months } & .821 \\ \text { Anxiousness last } 6 \text { months } & .793 \\ \text { Nervousness last } 6 \text { months } & .619\end{array}$

Factor 2.

Parent's education

$\begin{array}{ll}\text { Father's education } & .808 \\ \text { Mother's education } & .773\end{array}$

Factor 3.

Order of birth and number of children in family

$$
\begin{aligned}
& \text { Order of birth } \\
& \text { Number of children in family }
\end{aligned}
$$

Factor 4.

Somatic manifestations

$\begin{array}{ll}\text { Headaches in last } 6 \text { months } & .714 \\ \text { Stomach pains/cramps last 6 months } & .651 \\ \text { Back pains last six months } & .599\end{array}$

Factor 5 .

Physical activity

$\begin{array}{ll}\text { Walking/running last } 7 \text { days } & .737 \\ \text { Physical exercise last } 7 \text { days } & .606 \\ \text { Driving bicycle last } 7 \text { days } & 644\end{array}$

Factor 6.

Meat meals

$$
\text { Eating fast food last } 7 \text { days }
$$

Meat meals last 7 days

Factor 7.

Fruit and vegetable

Consummation of vegetables yesterday $\quad .748$

Consummation of fruit yesterday $\quad .626$

Factor 11.

Alcohol

At least one glass of alcoholic drink during meal in last 30 days

Factor 12 .

Time spent playing video and computer games Time spent working on PC, including playing video and computer games

weight and obese. Function 1 discriminate well normal weight group (group centroid 0.086) from overweight (group centroid -0.315) and obese group (group centroid $-0.376)$

Normal weight group is described with higher number of children in the family and higher order of birth, lower education of parents, they eat more vegetables and fruits, spend less time playing computer games, have 
TABLE 5

DISCRIMINANT ANALYSIS

Predictive variables 12 Factors

Structure Matrix

\begin{tabular}{lc}
\hline & Function 1 \\
Factor 3 & 0.623 \\
Factor 2 & -0.465 \\
Factor 7 & 0.304 \\
Factor 12 & -0.282 \\
Factor 5 & 0.260 \\
Factor 11 & -0.067 \\
\hline Discriminate variables & Group centroid \\
\hline BMI $\quad$ Group 1 - Normal weight & 0.089 \\
$\quad$ Group 2 - Overweight & -0.315 \\
$\quad$ Group 3 - Obesity & -0.376 \\
\hline
\end{tabular}

$\mathrm{p}=0.010\left(\chi^{2}=42.890 ; \mathrm{df}=24\right)$

more physical activity, drink less alcohol with their meals. Overweight and obese groups is described with lower number of children in the family and lower order of birth, higher education of parents, they eat less vegetables and fruits, spend more time playing computer games, have less physical activity, drink more alcohol with their meals (Figure 1).

\section{Discussions and Conclusion}

Results of our study showed presence of well known risk factors for overweight and obesity in 7-8 year old children. Characteristic finding in our study different from other studies is presence of higher parent's level of education and presence of alcohol intake in children among overweight and obese groups. Lazarou in Cyprus studied children mean age 10.7 years found that girls watching television 4 hours and more per day are three time more overweight, same wasn't significant in boys ${ }^{6}$. Investigating white and Asian children aged 7-10 in United Kingdom Khunti showed that in both groups $46 \%$ of children spent 4 and more hours per day watching television and playing computer games ${ }^{7}$. In California USA Matheson find that a significant proportion of children's daily energy intake is consumed during television viewing and that consumption of high fat food during weekends may be increased with BMI in younger children $^{8}$. In rural parts of Ohio USA eating breakfast at home and in school with increased hours watching television is associated with higher BMI especially in boys aged 6-11 years ${ }^{9}$. In Brazil Guedes find that among children aged 15-18 years overweight is connected with fats intake and elevated blood pressure with sedentary behavior and smoking ${ }^{10}$. In Norway among adolescents aged 13-19 years Fasting showed that less physically activity is connected with higher prevalence of overweight and obesity, paradoxically those children with healthy eating habits are more overweight than those without it ${ }^{11}$. Investigating children aged 6-8 in Spain Garces showed that correction of poor diet at an early age would have significant benefits for the prevention of cardiovascular disease ${ }^{12}$. Collison showed positive correlation between drinking sugar sweetened drinks and increased BMI among boys aged 10-19 in Saudi Arabia ${ }^{13}$. In Germany at children aged 3-17 years Kleiser found that lower socio economic status and parental overweight could be determinant of obesity ${ }^{14}$. Single household children in Florida USA were significantly more overweight than dual parent household's children and have significantly higher total calorie and fatty acid intake, Huffman ${ }^{15}$. Portuguese children aged 5-10 years were investigated by Moriera, obesity was negatively associated with pastry, cookies food pattern and positively associated with yogurt, cheese and ice cream intake ${ }^{16}$. Considering all stated above there are phew points of action. One is increased physical activity as shown in Gidding's study among children aged 8-10: For BMI, an analysis of intense physical activity showed that for every 10 hours of intense activity, there was a trend toward significance with a $0.2 \mathrm{~kg} / \mathrm{m}^{2}$ decrease ${ }^{17}$. Van Sluijs study on 10 year old children in United Kingdom showed that intervention target should be keeping level of achieved physical activity rather than targeting increased levels with increased intake of fruit and vegetables possibly focused on children from lower socio economic background ${ }^{18}$. Results of The Bogalusa Heart Study express need for additional data collection to establish connection between childhood weight status and cardiovascular morbidity and emphasize need for primary and secondary prevention $^{19}$. American Medical Association Expert Committee Recommendations establish that $18.8 \%$ of children aged 6-11 years and $17.4 \%$ of children aged 12-19 years in USA are obese. Measures for control and prevention are recommended: anthropometric measurements, lifestyle changes, dietary habits and laboratory testing if necessary ${ }^{20}$.

In conclusions: our study results show need to investigate why overweight and obese children come from families with parent's higher education level what is opposed with findings of other authors. We could assume that parents with lower education spend more time at home with their children (more time for cooking?). Multicentric studies with larger number of participants are needed to establish is that a pattern which describes these groups.

\section{Acknowledgements}

The study was supported by Ministry of Health and Social Welfare Republic of Croatia and Canadian Society for International Health and Ministry of Science, Education and Sport. 


\section{R E F E R E N C E S}

1. WORLD HEALTH ORGAN TECH REP SER, 849 (2000) 1. - 2 ST-ONGE MP, KELLER KL, HEYMSFIELD SB, Am J Clin Nutr, 78 (2003) 1068. - 3. CANADIAN SOCIETY FOR INTERNATIONAL HEALTH, 2003 Croatian Adult Health Survey - Users guide (Canadian Society for International Health, 2003). - 4. JURESA V, MUSIL V, KUJUNDŽIĆ-TILJAK M, Coll Antropol, 36 Suppl 1 (2012). - 5. COLE TJ, BELLIZZI MC, FLEGAL KM, DIETZ WH, BMJ, 320 (2000) 1240. 6. LAZAROU C, SOTERIADES ES, Eur J Pub Health, 20 (2009) 70. - 7. KHUNTI K, STONE MA, BANKART J, SINFIELD PK, TALBOT D, FAROOQI A, DAVIES MJ, Fam Pract, 24 (2007) 237. - 8. MATHESON DM, KILLEN JD, WANG Y, VARADY A, ROBINSON TN, Am J Clin Nutr, 79 (2004) 1088 - 9. MONTGOMERY-REAGAN K, BIANCO JA, HEH V, RETTOS J, HUSTON RS, Journal of Rural Health, 9 (2009) 1234. - 10. GUEDES DP, GUEDES JE, BARBOSA DS, DE OLIVEIRA JA, STANGANELLI LC, Arq Bras Cardiol, 86 (2006) 439. — 11. FASTING MH, NILSEN TI, HOLMEN TL, VIK T, BMC Public Health, 8 (2008) 111. - 12 GARCÉS C, DE OYA M; INVESTIGADORES DEL ESTUDIO CUATRO
PROVINCIAS, Rev Esp Cardiol, 60 (2007) 517. - 13. COLLISON KS, ZAIDI MZ, SUBHANI SN, AL-RUBEAN K, SHOUKRI M, AL-MOHANNA FA, BMC Pub Health, 10 (2010) 234. - 14. KLEISER C, SCHAFFRATH ROSARIO A, MENSINK GBM, PRINZ-LANGENOHL R, KURTH BM, BMC Public Health, 9 (2009) 46. - 15. HUFFMAN FG, KANIKIREDDY S, PATEL M, Int J Environ Res Public Health, 7 (2010) 2800 - 16. MOREIRA P, SANTOS S, PADRAO P, CORDEIRO T, BESSA M, VALENTE H, BARROS R, TEIXERA V, MITCHELL V, LOPES C, MOREIRA A, Int J Environ Res Public Health, 7 (2010) 1121 - 17. GIDDING SS, BARTON BA, DORGAN JA, KIMM SYS, KWITWROVICH PO, LASSER NL, ROBSON AM, STEVENS VJ, VAN HORN L, SIMONS- -MORTON DG, Pediatrics, 118 (2010) 2388. — 18. VAN SLUIJS EMF, SKIDMORE PML, MWANZA K, JONES AP, CALLAGHAN AM, EKELUND U, HARRISON F, HARVEY I, PANTER J, WAREHAM NJ, CASSIDY A, GRIFFIN SJ, BMC Public Health, 8 (2008) 2458. - 19. FREEDMAN DS, KHAN LK, DIETZ WH, SRINIVASAN SR, BERENSON GS, Pediatrics, 108 (2001) 712. — 20. RAO G, Am Fam Physician, 78 (2008) 56.

\section{Jureša}

University of Zagreb, School of Medicine, »Andrija Štampar« School of Public Health, Rockefeller Street 4, 10000 Zagreb, Croatia

e-mail:vjuresa@snz.hr

\section{NAVIKE I PONAŠANJA U ŠKOLSKE DJECE S PREKOMJERNOM TJELESNOM TEŽINOM I PRETILOŠĆU}

\section{S A Ž E T A K}

Cilj rada je odrediti socio ekonomske, zdravstvene, prehrambene i razlike u ponašanju debele, prekomjerno uhranjene djece i normalno uhranjene djece učenika prvog razreda osnovne škole. Prosječna dob naših ispitanika je 7,5 godina. Prema Colovim standardima prekomjerno teško je 13,8\% dječaka i 12,6\% djevojčica, a debelo je $8,3 \%$ dječaka i $6,9 \%$ djevojčica. Varijable dobivene istraživanjem uključene su u faktorsku analizu i dobiveno je 12 faktora koji objašnjavaju 60\% varijabilnosti. Diskriminacijska analiza učinjena je s 12 faktora kao prediktivnim varijablama, dobivene su dvije funkcije od kojih je samo 1 bila interpretabilna. Funkcija 1 opisana je sa: »Red rođenja i brojem djece u obitelji«, "Obrazovanjem roditelja«, "Konzumacija voća i povrća«, »Vremenom provedenim igrajući kompjutorske igre i gledanjem videa«, "Fizička aktivnost« $\mathrm{i}$ »Pijenje alkohola«. Diskriminacijske varijable bile su tri grupe obzirom na BMI: normalno uhranjeni, prekomjerno uhranjeni i debeli. Funkcija 1 dobro je razdvojila normalno uhranjene (grupni centroid 0,086 ) od prekomjerno uhranjenih (grupni centroid -0,315) i debelih (grupni centroid -0,376). Normalno uhranjeni opisani su većim brojem djece u obitelji i višim redom rođenja, nižim obrazovanjem roditelja, jedu više voća i povrća, provode manje vremena igrajući se na kompjutoru, više su fizički aktivni i piju manje alkohola. Prekomjerno uhranjeni i debeli opisani su manjim brojem djece u obitelji i nižim redom rođenja, višim obrazovanjem roditelja, jedu manje voća i povrća, provode više vremena igrajući se na kompjutoru, manje su fizički aktivni i piju više alkohola. U zaključku možemo reći da su rezultati ovog istraživanja pokazali već poznate razlike u čimbenicima rizika za debele i prekomjerno teške. Ono što razlikuje našu studiju od drugih je podatak da su debeli i prekomjerno uhranjeni iz obitelji s višom razinom obrazovanja roditelja. Moguce uzroke ove pojave trebalo bi dodatno istražiti. 